Aliran Eksistensialisme dalam Pandangan Filsafat Pendidikan Islam

Rabiatul Adawiah

Madrasah dan Transformasi Intelektual Muhdi

Kisah Keluarga Teladan dalam Al-Qur'an (Inspirasi Membangun Negara yang Thayyibah) Rahmat Sholihin

Tasawuf dalam Pandangan Nurcholish Madjid Ilham Masykuri Hamdie dalam Buku The Tao of Islam) Erni Susilawati

Islam, Keindonesiaan, dan Kemanusiaan

(Telaah Pemikiran Ahmad Syafii Maarif) Damanhuri

Pandangan Kritis Islam Liberal atas Isu-Isu Kontemporer Muhammad Taufik 


\section{AL - BANJARI \\ Jurnal Ilmiah Ilmu-Ilmu Keislaman}

Vol. 14, No. 1, Januari-Juni 2015

\section{DAFTAR ISI}

Aliran Eksistensialisme dalam Pandangan Filsafat Pendidikan Islam

Rabiatul Adawiah

Madrasah dan Transformasi Intelektual

Muhdi

Kisah Keluarga Teladan dalam Al-Qur'an (Inspirasi Membangun

Negara yang Thoyyibah)

Rahmat Sholihin

Tasawuf dalam Pandangan Nurcholish Madjid

Ilham Masykuri Hamdie

Psikologi Sufistik (Studi atas Pemikiran Sachiko Murata dalam Buku

The Tao of Islam)

60-75

Erni Susilawati

Islam, Keindonesiaan, dan Kemanusiaan (Telaah Pemikiran

Ahmad Syafii Maarif)

$76-84$

Damanhuri

Pandangan Kritis Islam Liberal atas Isu-Isu Kontemporer

85-105

Muhammad Taufik 


\title{
TASAWUF DALAM PANDANGAN NURCHOLISH MADJID
}

\author{
Ilham Masykuri Hamdie \\ IAIN Antasari Banjarmasin
}

\begin{abstract}
Although Sufism is not a central theme of Nurcholish Madjid works, this article will discuss aspects of Sufism in Nurcholish Madjid's point of view because his ideas of renewal which is loaded with depth of knowledge, modernity and humanity, show an appreciative attitude towards Sufism. This discussion found that Nurcholish Madjid notice the essence of diversity in Sufism such as taqarrub, the meaning of worship, akblak al-karimah (good deed), and actively involved in social life. Those points are very relevant to religious life now and in the future.
\end{abstract}

Keywords: Sufism, Nurcholish Madjid, Akhlak al-Karimah, and Religious Life

\section{Pendahuluan}

Sejak munculnya gerakan modernisme dalam Islam, tasawuf terus menjadi bulanbulanan untuk dikritik, paling tidak, atas tiga tuduhan. Pertama, atas sikapnya yang terlalu familier terhadap praktek-praktek keagamaan yang dinilai palsu. Kedua, pembawaannya yang cenderung mengingkari dunia berikut perlambang-perlambangnya. Dan ketiga, ia telah menjadi penyebab mundurnya umat Islam lantaran wataknya yang merusak intelektualisme dan rasionalisme. ${ }^{1}$

Tidak hanya di sekolah-sekolah yang didirikan oleh kelompok modernis, tetapi di madrasah-madrasah-pun, tasawuf bukan lagi dianggap sebagai mata pelajaran yang mesti diberikan kepada para murid. Tasawuf seolah-olah bukan anak yang sah dari Islam. Lalu, mengapa sekarang tasawuf kembali memperoleh perhatian ?, dan bahkan cenderung meningkat.

Kaum modernis memang sangat berjasa dalam mengembangkan penafsiran dan pemikiran keagamaan. Kalau alam pikiran kaum fuqaha lebih menekankan agama sebagai "hukum", maka kaum modernis memekarkannya menjadi semacam "ideologi". Namun perbedaan itu tidaklah bersifat prinsipil, pada dasarnya pola keberagamaan disitu tetaplah sama. Tuhan lebih dihayati sebagai "al-Hakim”, Sang pemberi Syari'at untuk mengatur peri-kehidupan manusia, sedangkan manusia hanyalah "mukallaf",

\footnotetext{
${ }^{1}$ Lihat Djohan Effendi, Sufisme : Esensi dan Masa Depan Agama, dalam, Djohan Effendi (Peny), Sufisme Dan Masa Depan Agama, (Jakarta : Pustaka Firdaus, 1993), hal. 117-118.
} 
makhluk yang diberi beban untuk melaksanakan syari'at. Karena itu, keberagamaan semacam ini oleh sebagian orang dirasakan kurang memberikan peluang untuk menghayati dimensi kedalaman dari agama. Padahal justeru pada dimensi kedalaman itulah terletak "inti keberagamaan". Disinilah terletak pentingnya fungsi tasawuf.

Lalu bagaimana sesungguhnya para modernis Islam, khususnya Nurcholish Madjid memandang tasawuf atau sufisme itu? Apakah ia, seperti kebanyakan tokoh modernis Islam yang menunjukkan sikap anti tasawuf, dan bahkan tidak jarang, langsung menyamakan cabang keilmuan Islam tradisional ini sebagai "bid'ah" yang harus diberantas.

\section{Riwayat Hidup dan Karya-karya Nurcholish Madjid:}

Keberadaan Nurcholish Madjid sebagai salah satu pemikir modern dalam wilayah intelektual Indonesia, tidak disangsikan lagi. Sebagai tokoh neo-modernisme dalam wacana pembaharuan pemikiran Islam Indonesia, di satu sisi kehadirannya mampu mendobrak tatanan pola pemikiran Islam dengan menghadirkan suasana baru ketika berhadapan dengan teks-teks Islam. Dan di sisi lainnya, secara genial ia mampu memadukan gagasan-gagasan yang ada dalam berbagai tradisi yang berbeda.

Nurcholish Madjid, yang akrab dipanggil dengan sebutan Cak Nur ini, lahir di Jombang, Jawa Timur 17 Maret 1939 (26 Muharram 1358) dari keluarga kalangan pesantren. Setelah menamatkan pendidikan Sekolah Rakyat (pagi) dan Madrasah Ibtidaiyah al-Wathoniyah (sore) di Mojoanyar, milik ayahnya KH. Abdul Madjid, yang juga salah satu murid KH. Hasyim Asy’ari, pendiri Nahdatul Ulama. KH. Abdul Madjid, adalah tokoh awal yang banyak memberi pengaruh besar pada pendidikan dan pemikiran Nurcholish Madjid ini, adalah seorang tokoh yang berwawasan luas. Meski sering dipanggil "Kiai Haji", sebagai ungkapan penghormatan bagi ketinggian ilmu-ilmu keislaman yang dimilikinya, ia sendiri secara pribadi tidak pernah menyebut dirinya kiai dan tidak pernah secara resmi "bergabung dengan kalangan ulama". Meskipun lahir dalam tradisi NU, namun ia menolak jaringan ulama NU dan bergabung dengan partai politik NU. Sebagai gantinya, ia menjadi anggota dan pendukung setia Masyumi, meskipun ulama tradisional lainnya meninggalkan Masyumi.

Karena pandangan politik ayahnya mengikuti Masyumi itulah kemudian yang menyebabkan Nurcholish Madjid yang ketika belajar di pesantren Darul Ulum Rejoso Jombang, ia dianggap "anak Masyumi yang kesasar" sehingga harus pindah belajar ke KMI (KulliyatulMu'allimin al-Islamiyah) Pondok Modern Gontor Ponorogo, sampai tamat $1960 .^{2}$

Selain pengaruh yang dominan dari ayahnya, nampaknya, Gontor adalah unsur lain yang cukup berpengaruh terhadap perkembangan intelektual Nurcholish Madjid. Ia berumur 16 tahun saat masuk dan selesai tahun 1960 ketika ia berumur 21 tahun. Dan kelihatannya corak pemikiran modern mulai didapatkannya di Gontor, yang dikenal sebagai sebuah pesantren yang menggembleng para santrinya untuk menguasai bahasa asing (khususnya Arab dan Inggeris), dan berlatih berpikir komparatif, serta bebas sehingga tidak mudah terjebak pada fanatisme madzhab.

\footnotetext{
${ }^{2}$ Sebagaimana diungkapkan Cak Nur dalam wawancara dengan Sudirman Tebba, Budiarto Danujaya dan H. Azkarmin Zaini dari Kompas, Minggu, 3 Nopember 1985.
} 
Pengalaman pendidikan di Gontor inilah yang kemudian menjadi andalan bagi kelanjutan belajar Nurcholish Madjid, sehingga menghasilkan keluasan wawasan yang dijadikan bekal saat pergi ke Jakarta pada tahun 1961, setelah mengajar selama setahun lebih di Gontor. Dengan bakat akademik yang luar biasa, ia pindah ke Jakarta melanjutkan studi ke jenjang perguruan tinggi di IAIN Syarif Hidayatullah (sekarang Universitas Islam Negeri Jakarta), dan lulus dari Fakultas Adab jurusan Sastra Arab dan Kebudayaan Islam 1968, dengan menulis skripsi berjudul Al-Qur'an 'Arabiyan Lughatan wa 'Alamiyan Ma'nan (Al-Qur'an secara bahasa adalah Bahasa Arab, secara makna adalah Universal).

Selama menjadi mahasiswa, ia aktif dalam gerakan dan kegiatan kemahasiswaan, khususnya di Himpunan Mahasiawa Islam (HMI), sebuah organisasi kemahasiswaan dari sayap Islam yang cukup liberal, dan dianggap memiliki reputasi besar dalam gerakan kaum modernis sehingga dianggap sebagai mitra kerja Masyumi. Adapun alasan keterlibatan Nurcholish Madjid di HMI ini, menurut Greg Barton, disebabkan pengaruh ayahnya, agar ia memiliki rasa hormat tinggi pada pemimpin-pemimpin Masyumi seperti Mohammad Natsir. ${ }^{3}$

Nurcholish Madjid menjadi Ketua Umum Pengurus Besar HMI untuk dua periode, 1966-1969 dan 1969-1971. Ia juga pernah menjabat Presiden PEMIAT (Persatuan Mahasiswa Islam Asia Tenggara) 1967-1969. Juga menjadi Asisten Sekjen IIFSO (International Islamic Federation of Students Organizations), 1969-1971. Kepemimpinan Nurcholish Madjid dalam organisasi kemahasiswaan ini merupakan hal amat penting dalam jalur intelektualisme kehidupannya, dan memberi sumbangan berharga terhadap perkembangan intelektualnya.

Nurcholish Madjid mulai dikenal menonjol dengan gerakan pembaharuannya di mata masyarakat setelah ceramahnya yang menghebohkan pada 3 Januari 1970 setelah ia menyajikan makalah "Keharusan Pembaruan Pemikiran Islam dan Masalab Integrasi Umat". Dalam makalah itu ia secara bebas dan transparan berbicara mengenai keharusan pembaruan dalam pemikiran islam Modernis di Indonesia dengan mengupas secara jelas tentang 'sekularisasi', 'desakralisasi', 'liberalisme' dan sosialisme'. Sejak itulah Nurcholish Madjid dipublikasikan secara besar-besaran . Pada mulanya ia dianggap "anak emas" oleh para tokoh Masyumi, hingga sempat dipuji sebagai 'Natsir Muda', tetapi kemudian dihujat dan dianggap berbalik 180 derajat dari lintasan yang konservatif.

Selain dalam dunia kemahasiswaan, Nurcholish Madjid yang tidak pernah absen berkiprah dalam dunia ilmiah ini, pernah menjadi Pemimpin Umum Majalah MIMBAR, Jakarta, 1971-1974, sebuah penerbitan majalah Islam yang provokatif menyebarkan ide-ide pembaruan ke tengah masyrakat luas. Nurcholish Madjid kemudian juga bersama teman-temannya, mendirikan dan memimpin LSIK (Lembaga Studi Ilmu-Ilmu Kemasyarakatan), 1972-1976, serta LKIS (lembaga Kebajikan Islam Samanhudi), 1974-1977. Yayasan Samanhudi adalah yayasan tempat berkumpulnya intelektual muda yang melahirkan berbagai gagasan. Disinilah Nurcholish Madjid sering bertemu dengan tokoh pemikir modernis lainnya seperti Djohan Effendi, ${ }^{3}$ Lihat, Greg Barton, Gagasan Islam Liberal di Indonesia, terj. Nanang Tabqiq, Jakarta : Paramadina, 1999), hal. 78. 
Ahmad Wahib, Dawam Rahardjo, Syu'bah Asa, dan Abdurrahman Wahid. Kemudian kelompok ini ternyata berlanjut pada pembentukan pertemuan 'Reboan' di tahun 1980-1n dan 1990-an, dan melalui kegiatan-kegiatan tidak resmi semacam ini gerakan Pembaruan Pemikiran Islam kemudian tumbuh dan berkembang. ${ }^{4}$

Pada tahun 1978 Nurcholish Madjid berangkat ke Amerika Serikat mengambil program Pasca sarjana di University of Chicago dengan didanai Ford Foundation. Dan di sana Prof. Fazlurrahman, seorang pemikir Islam Neo-Modernis mengajaknya untuk mengambil penelitian di bidang kajian keislaman (di bawah bimbingannya). Gelar doktor dalam bidang Kalam dan Filsafat diperolehnya tahun 1984 diperolehnya dengan nilai Cum Laude, dengan judul disertasi-doktor Ibn Taymiya on Kalam and Falsafah : A Problem of Reason and Reveletion in Islam (Ibn Taymiyah dalam Ilmu Kalam dan Filsafat: Masalah Akal dan Wahyu dalam Islam).

Tahun 1984, ketika Nurcholish Madjid kembali ke Indonesia setelah enam tahun belajar di Chicago tersebut, beberapa teman beserta pendukungnya mulai mengadakan pertemuan untuk melanjutkan ide-ide pembaruannya. Pertemuan yang dipimpin Utomo Dananjaya ini merasa berkepentingan untuk menciptakan kendaraan organisasi yang tepat bagi maksimalisasi potensi yang membawa perubahan dalam umat Islam. Setelah dipertimbangkan secara matang, diputuskan bahwa lembaga baru harus didirikan dengan nama "Paramadina". Dengan organisasi yang disusun oleh teman-temannya yang terpecaya ini, Nurcholish Madjid bebas untuk mengembangkan ide-idenya, dan menyalurkan sepenuhnya energi aktivitas intelektualnya.

Nurcholish Madjid yang menikah tahun 1969 dengan Omi Qomaria, dengan beroleh sepasang permata hati, Nadia Madjid dan Ahmad Mikail ini, tetap menjadi dosen di UIN Jakarta dan berkutat di bidang riset sebagai peneliti di LIPI (Lembaga Ilmu Pengetahuan Indonesia). Namun demikian tetap 'Paramadina'-lah yang menjadi kendaraan utamanya dan merupakan fokus energinya. Di sinilah tokoh pemikir pergerakan Islam ini, banyak menulis makalah-makalah dan buku-buku yang diterbitkan dan menyebar dalam beberapa koran, majalah, buku, dan suntingan. Dan demi alasan-alasan strategis, konsentrasi aktivitas ini adalah pada usaha mempengaruhi kelompok yang paling berpengaruh, kelas menengah atas.

Di antara karya-karya Ketua dan sekaligus pendiri Yayasan Wakaf Paramadina dan bekas anggota Komnas HAM RI dan kini Rektor Universitas Paramadina Mulya ini, yang sudah diterbitkan : Khazanah Intelektual Islam (Jakarta : Bulan Bintang 1986); Islam kemodernan dan Keindonesiaan (Bandung: Mizan 1988); Islam Doktrin dan Peradaban, Sebuah Telaan Kritis tentang Masalah Keimanan, kemanusiaan dan Kemodernan (Jakarta : Paramadina, 1992); Islam Kerakyatan dan Keindonesiaa (Bandung : Mizan, 1993); PintuPintu menuju Tuhan (Jakarta : Paramadina, 1994); Islam Agama Kemanusiaan: Membangun Tradisi dan Visi Baru Islam (Jakarta : Paramadina, 1995); Islam Agama Peradaban (Jakarta : Paramadina, 1995); Kaki Langit Peradaban Islam (Jakarta : Paramadina, 1997); Tradisi Islam : Peran dan Fungsinya dalam Pembangunan di Indonesia (Jakarta : Paramadina, 1997); Masyarakat Religius (Jakarta : Paramadina, 1997); Perjalanan Religius 'Umrab dan Haji Jakarta : Paramadina, 1997); Bilik-Bilik Pesantren (Jakarta : Paramadina, 1997); Dialog Keterbukaan, Artikulasi Nilai Islam dalam Wacana Sosial Politik. Kontemporer (Jakarta :

${ }^{4}$ Lihat, Ibid., hal. 83-84. 
Paramadina, 1998); Pemikiran Politik Islam Era Reformasi (Jakarta : Paramadina, 1999). Dan lain-lainnya.

Diantara karya-karyanya dalam bahasa Inggeris adalah "The Issue of Modernization among Muslims in Indonesia : From a Participant's Point of View dalam Gloria Davies (Ed.) What is Modern Indonesian Cultrures? (Athens, Ohio, University of Ohio Southeast Asia Studies, 1979); "Islam in Indonesia : Challenges anf Opportunities" dalam Cyriac K. Pullapilly (Ed.), Islam in the Contemporary World (Notre Dame, Indiana, Cross Roads Books, 1980).

Dari beberapa pemikiran Nurcholish Madjid, banyak yang mengundang kontroversi seperti gagasan tentang partai politik (Islam, Yes; Partai Islam, No), ide sekularisasi tentang masalah-masalah keduniaan, teologi dan masih banyak lagi. Pemikiran-pemikirannya ini telah banyak mempengaruhi kalangan intelektual muda, dan sering menjadi obyek penelitian untuk tesis dan disertasi, ${ }^{5}$ sehingga oleh beberapa teman-temannya di Amerika Serikat, ia digelari sebagai "The Living Legend".

Secara sederhana pemikiran Nurcholish Madjid dapat disimpulkan sebagai "mengartikulasikan" tiga ranah keilmuan yaitu akar keilmuan klasik, wawasan kemodernan dan sekaligus persentuhannya dengan persoalan keindonesiaan. Mengapa gagasan-gagasan Nurcholish Madjid sering dan selalu dianggap kontroversial dan menjadi sasaran kritik. Salah satu sebabnya, barangkali adalah karena Nurcholish Madjid adalah tipe pemikir yang independen, yang tidak memiliki obsesi untuk memperoleh massa pengikut, kecuali setia pada tradisi dan sikap keilmuan serta obsesi untuk selalu mendekati kebenaran meski kadangkala harus berbeda dari pemahaman ulama umumnya yang telah melembaga dan menjadi ideologi. ${ }^{6}$

Memang Nurcholish Madjid adalah sebuah fenomena untuk konteks masyarakat Indonesia. Sifat fenomenal tokoh ini, menurut Fachry Ali dapat dilihat pada fakta bahwa kekuatan pribadi dan pemikirannya yang mampu melahirkan pengaruh terhadap perubahan-perubahan tertentu di dalam masyarakat Indonesia, baik yang bersifat literal maupun institusional. Secara literar, kehadiran Nurcholish Madjid telah memperkaya khazanah literatur intelektual di negara kita, ini ditandai bukan saja oleh publikasi pemikiran-pemikirannya, maupun publikasi studi-studi tentang dirinya, yang dengan sendirinya melahirkan dinamika intelektual. Melalui karya-karya itu, kita bukan saja mendapat bahan untuk memahami dunia intelektual Indonesia, melainkan juga memberikan landasan bagi perdebatan dan pengelanaan intelektual lebih lanjut bagi generasi-generasi mendatang. ${ }^{7}$

Secara institusional, hasil dari pengaruh Nurcholish Madjid bisa terlihat dalam wujud dan kinerja spesifik organisasi HMI di masa kepemimpinannya dan beberapa

\footnotetext{
5 Studi yang dilakukan antara lain oleh Kamal Hasan untuk disertasinya di Columbia University, “Indonesian Muslim Intellectual Responses to the Issue of Modernization". Lalu diikuti oleh Victor Tanja, tentang HMI, dan Greg Barton dari Monash University, Australia. Studi terbaru dilakukan oleh Masykuri Abdillah dari Universitas Hamburg dengan judul "Responses of Indonesian Muslim Intellectual to the Concept of Democracy (1966-1993)".

${ }^{6}$ Lihat, Kata Pengantar Komaruddin Hidayat pada, Nurcholish Madjid, Islam Agama Peradaban : Membangun Makna dan Relevansi Doktrin Islam dalam Sejarah, (Jakarta : Paramadina, 1995), hal. viii. ${ }^{7}$ Lihat, Fachry Ali, Kata Pengantar, dalam, Nurcholish Madjid, Dialog Keterbukaan: Artikulasi Nilai Islam dalam Wacana Sosial Politik Kontemporer, (Jakarta : Paramadina, 1998), hal. xxii.
} 
periode setelah itu. Tapi pengaruh institusional yang paling mencolok adalah yayasan Paramadina. Melalui lembaga ini, Nurcholish Madjid meletakkan pengaruhnya bukan saja pada sosialisasi pemikiran-pemikirannya, melain juga pada terbentuknya sebuah komunitas tertentu -walau masih samar-samar-yang menjadi pendukungnya dari kalangan santri kota. ${ }^{8}$

Lewat Yayasan Paramadina yang didirikannya, Nurcholish Madjid kerap mengadakan forum kajian keagamaan terutama untuk kalangan kelas menengah kota secara rutin setiap bulan. Pesona pemikirannya tersosialisasi lewat buku-buku, ceramah, kuliah dan layar televisi. Simpul pemikiran Nurcholish Madjid adalah monoteisme radikal dan kemodernan, variannya antara lain gagasan tentang sekularisasi, inklusivisme, serta universalisme Islam. Sekularisasi versi Nurcholish Madjid adalah "menduniawikan nilai-nilai yang semestinya bersifat duniawi dan melepaskan umat Islam dari kecenderungan meng-akheratkannya". Gagasan inklusivisme Islamnya tercermin dalam pendapatnya bahwa, "Islam tidak identik dengan ideologi", sedangkan gagasan kemodernannya terartikulasikan lewat jargon "modernisasi adalah rasionalisasi, bukan westernisasi”.

Ikon pembaruan pemikiran dan gerakan islam di Indonesia yang populer dipanggil Cak Nur meninggal dunia 29 Agustus 2005 akibat penyakit sirosis hati yang dideritanya. Meskipun hanya sebagai warga sipil, tapi karena dianggap telah banyak berjasa kepada negara hingga dianegerahi Bintang Maha Putera, beliau dimakamkan di Taman Pahlawan Kalibata Jakarta.

\section{Orientasi Tasawuf dalam Pemikiran Nurcholish Madjid}

Tidaklah berlebihan kiranya jika disebutkan bahwa Nurcholish Madjid adalah seorang pemikir Islam modernis yang paling terkemuka di Indonesia. Sebagai seorang juru bicara kaum modernis Indonesia, ia dengan fasih mengungkapkan pemikirannya secara mendalam dengan bahasa yang jernih, kaya ilustrasi dan sarat dengan kutipan al-Qu'an dan rujukan kitab kuning. Dalam kaitan dengan tasawuf, nampaknya Nurcholish Madjid rmemiliki sedikit keunikan, antara lain terletak dalam kenyataan bahwa beliau seorang modernis yang mendorong reformasi pemikiran Islam, bahkan termasuk seorang pelopor dan pemimpin garda terdepannya. Namun berbeda dengan kebanyakan kaum modernis lainnya, beliau menunjukkan minat dan perhatian intelektual yang cukup besar terhadap tasawuf. Walaupun tidak ditemukan buku-buku hasil karyanya yang secara khusus menguraikan tentang tasawuf, namun dari beberapa tulisan-tulisan yang bertebaran dapat ditemukan noktah-noktah pandangannya tentang aspek esoteris dari ajaran Islam ini. Berikut ini adalah sebagian dari pandangan-pandangannya tentang tasawuf.

\section{Kedudukan Sufisme dalam Islam.}

Menurut Nurcholish Madjid secara tradisional tasawuf termasuk salah satu cabang ilmu pengetahuan tradisional Islam, selain fiqih, ilmu kalam, dan filsafat. Semuanya lahir secara sendiri-sendiri, tetapi saling berkait. ${ }^{9}$ Kelahirannya sebagai

${ }^{8}$ Ibid.

9 Nurcholish Madjid, "Tasawnf sebagai Inti Keberagamaan" dalam Majalah Pesantren, No.3/Vol. II/1985, hal. 3 . 
disiplin ilmu tersendiri, adalah sebagai kelanjutan wajar dari keperluan kepada adanya semacam differensiasi ilmu pengetahuan Islam dalam abad-abad kedua dan ketiga Hijrah. ${ }^{10}$

Ketika Islam mencapai sukses yang luar biasa sepeninggal Rasulullah khususnya di bidang militer dan politik, membawa berbagai akibat yang sangat luas. Salah satunya adalah perhatian yang amat besar pada bidang-bidang pengaturan masyarakat. Maka tidaklah mengherankan bahwa dari berbagai segi agama Islam, yang paling awal memperoleh banyak penggarapan serius ialah yang berkenaan dengan hukum (fiqih), maka kesalehan-pun banyak dinyatakan dalam ketaatan kepada ketentuan hukum. ${ }^{11}$

Tetapi kesalehan yang bertumpu kepada kesadaran hukum itu, akan banyak berurusan dengan tingkah-laku lahiriah, dan hanya secara parsial saja berkaitan dengan hal-hal batiniah, maka menurut Nurcholish Madjid, tasawuf kemudian tumbuh menjadi dimensi lain dari penghayatan Islam yang telah semakin kehilangan dimensi batinnya (esoteris) akibat dominannya orientasi hukum yang berwatak eksoteris (hanya menekankan aspek lahiriah). Sejak itu menurutnya, mulai timbul pendalamanpendalaman kajian untuk memerangi "kekeringan" dimensi batin itu, dengan diperkaya oleh sentuhan-sentuhan dari agama lain dan unsur-unsur filsafat Yunani, khususnya Neo-platonisme untuk melakukan penafsiran-penafsiran metaforis. ${ }^{12}$

Begitu pula tentang inti ajaran al-Qur'an bahwa tauhid yang merupakan sesuatu yang tidak boleh diragukan, maka bagi bagi kaum sufi, al-Qur'an itu tidak hanya memuat ajaran-ajaran yang mengisyaratkan bahwa Tuhan itu serba transendental sebagaimana dipahami para mutakallimin, tetapi justru menurut para sufi, banyak ayat yang memberikan keterangan-keterangan yang menunjukkan Tuhan adalah serba immanen, senantiasa hadir bersama hamba-Nya dan selalu maujud dimana-mana. ${ }^{13}$

Memang menurut Nurcholish Madjid, hubungan antara tasawuf dengan kedua cabang ilmu-ilmu keislaman di atas tidak senantiasa harmonis. Namun, bahwa perbedaan itu pada awalnya, terutama antara tasawuf dan ilmu kalam, lebih terletak pada masalah tekanan daripada isi ajaran. Selain persoalan transendentalisme, ilmu kalam juga lebih mengutamakan pendekatan rasional dan logis, dan bersama syari'ah membentuk orientasi keagamaan yang lebih bersifat eksoteris. Sedangkan tasawuf sangat banyak menekankan pentingnya penghayatan ketuhanan melalui pengalamanpengalaman nyata dalam olah rohani (spiritual exercise) yang mengutamakan intuisi. ${ }^{14}$

Lebih jauh lagi, tasawuf itu pada mula kelahirannya menurut Nurcholish Madjid, juga tidak dapat dilepaskan dari gerakan oposisi terhadap praktek-praktek regimenter pemerintahan kaum Umawi di Damaskus. Memang sebagian oposisi itu terjadi karena dorongan politik semata, seperti oposisi orang Arab Irak. Tetapi sebagian lagi, justru lebih umum, oposisi itu timbul karena pandangan bahwa kaum Umawi itu kurang

\footnotetext{
${ }^{10}$ Nurcholish Madjid, Masyarakat Religius, (Jakarta : Paramadina, 1997), hal. 139.

${ }^{11}$ Lihat, Nurcholish Madjid, Islam Doktrin dan Peradaban : Sebuah Telaab Kritis tentang Masalab Keimanan, Kemanusiaan dan Kemodernan, (Jakarta : Paramadina, 1992), hal. 255.

${ }^{12}$ Nurcholish Madjid, "Tasawnf sebagai Inti....", hal. 3.

${ }^{13}$ Nurcholish Madjid, Bilik-Bilik Pesantren: Sebuab Potret Perjalanan, (Jakarta : Paramadina, 1997), hal. 45.

${ }^{14}$ Ibid., hal. 47.
} 
"religius". Disini ketokohan Hasan al-Basri dari Basrah yang peranannya tidak dapat dianggap sepele, adalah mewakili kelompok gerakan oposisi jenis ini. Para pengikutnya yang memiliki kecenderungan hidup zuhud (asketik) dengan pakaiannya dari bahan wol (shuf) inilah yang kemudian dianggap sebagai kaum sufi. ${ }^{15}$

Jadi jelas menurut Nurcholish Madjid, keberadaan tasawuf itu pada awalnya, merupakan "faktor pengimbang" bagi fiqih yang banyak menekankan segi hukum yang bersifat lahiri, dan bagi kalam yang lebih berorientasi rasional-dialektis. Tasawuf juga sebagai reaksi terhadap gejala kehidupan material yang mewah dan menyimpang hingga menimbulkan semacam gerakan-gerakan oposisi suci (pious opposition) di kalangan tertentu.

Dalam perkembangan sejarah Islam, ketika kejayaan politik Islam meredup, terutama karena serbuan Mongol dan ditambah oleh kemunduran ekonomi, menurut Nurcholish Madjid, kaum sufi telah berjasa memelihara semangat Islam dan eksistensinya dengan ribath (pos-pos kaum sufi) yang mereka dirikan di setiap kota. Dan karena kebiasaan mereka berkelana sambil singgah di tempat-tempat tertentu, menyebabkan perluasan daerah Islam, dan dengan cara seperti itulah pula Islam datang ke Indonesia. Jadi sejak saat itu, penyebaran Islam tidak lagi ditopang oleh kegiatan militer, melainkan diambil alih oleh kaum sufi. ${ }^{16}$

\section{Tasanuf sebagai Inti Keberagamaan}

Sebagaimana disebutkan bahwa kebanyakan tokoh pembaharu Islam menunjukkan sikap yang anti tasawuf dan bahkan menuduhnya sebagai bid'ah yang harus diberantas. Namun Nurcholish Madjid selain mengakui bahwa pada tasawuf itu terdapat berbagai gejala yang tidak bisa dibenarkan oleh ajaran Islam, ia masih tetap melihat adanya segi-segi yang otentik dalam tasawuf sebagai kelanjutan wajar dari semangat ajaran Islam itu sendiri, khususnya peneladanan kepada masyarakat klasik yang melahirkan konsep Salafiyah.

Sambil menolak pendapat para ahli yang hendak mereduksi misi Nabi Muhammad s.a.w. sebagai tidak lebih daripada suatu gerakan reformasi sosial, menurut Nurcholish Madjid bahwa Rasul itu membawa reformasi sosial kiranya sudah jelas, sebab al-Qur'an sendiri mengaitkan keimanan serta penerimaan seruan Nabi dengan usaha reformasi dunia, tetapi di berbagai tempat dalam al-Qur'an juga banyak penegasan tentang pentingnya orientasi keruhanian yang bersifat ke dalam dan mengarah kepada pribadi. Menurut Nurcholish Madjid Islam adalah agama pertengahan (wasath) antara orientasi legalistik dan kemasyarakatan seperti agama Yahudi, dan orientasi spiritualistik dan pengalaman rohani seperti agama Kristen. ${ }^{17}$

Selain sebenarnya, sudah sejak zaman Rasulullah s.a.w. sendiri, terdapat kelompok para sahabat Nabi yang lebih tertarik kepada hal-hal yang bersifat batiniah yang disebut kelompok abl al-shuffah, yang menjadi acuan teladan kehidupan shaleh di kalangan sahabat, menurut Nurcholish Madjid tasawuf itu mempunyai akar yang amat kuat (built-in) dalam al-Qur'an, jauh lebih kuat daripada orientasi hukum (fiqih). Secara sederhana jika misalnya dideretkan ayat-ayat yang relevan dengan hukum dan ayat-

\footnotetext{
${ }^{15}$ Nurcholish Madjid, Islam Doktrin dan ..., hal. 256.

${ }^{16}$ Lihat, Nurcholish Majid, "Tasawnf sebagai Inti ...", hal. 4.

${ }^{17}$ Nurcholish Madjid, Islam Doketrin dan ..., hal. 259-260.
} 
ayat yang relevan dengan ketasawufan, jelas lebih banyak deretan terakhir. Sebagai contoh perihal takwa, sebagai konsep sentral dalam al-Qur'an, menurut Nurcholish Madjid tidak dibicarakan oleh fiqih, pembahasan takwa justru selalu dijumpai pada bab fadha'il al-a'mal sebagai suatu aspek akhlak atau tasawuf. ${ }^{18}$

Karena itu jelas sekali bahwa Islam sebagai bentuk pertengahan antara orientasi lahiriah dan orientasi keruhanian, dan bahkan sesungguhnya antara keduanya itu tidak bisa dipisahkan, meskipun dapat dibedakan. Selanjutnya Nurcholish Madjid menegaskan :

Ketika seorang Muslim dituntut untuk tunduk kepada suatu hukum tingkah laku lahiriah, ia diharapkan, malah diharuskan, menerimanya dengan ketulusan yang terbit dari lubuk hatinya. Ia harus merasakan ketentuan hukum itu sebagai sebagai sesuatu yang berakar dalam komitmen spiritualnya. ${ }^{19}$

Tentang orientasi pengalaman spiritual itu, menurut Nurcholish Madjid, alQur'an sendiri memuat berbagai firman yang merujuk kepada pengalaman spiritual Nabi. Misalnya, gambaran tentang dua kali Nabi bertemu dan berhadapan dengan malaikat Jibril di gua Hira di atas Bukit Cahaya (Jabal Nur) dan bertemu Allah dalam perjalanan Isra dan Mi'raj. Bagi kaum sufi, pengalaman Nabi dalam Isra Mi'raj itu adalah sebuah contoh puncak pengalaman rohani. Dan para sufi menjadikannya sebagai teladan untuk ditiru bagi diri mereka sendiri, dalam dimensi, skala dan format yang sepadan dengan kemampuan mereka. Sebab inti pengalaman itu ialah penghayatan yang pekat akan situasi diri yang sedang berada di hadapan Tuhan, dan bagaimana ia "bertemu" dengan Dzat Yang Maha Tinggi itu, sebagai puncak kebahagiaan.Sebab dalam "pertemuan" itu, segala rahasia kebenaran "tersingkap" untuk sang hamba, dan sang hamba pun lebur dan sirna dalam Kebenaran. ${ }^{20}$

Akhirnya dari paparan di atas, jelaslah pandangan Nurcholish Madjid tentang kedudukan tasawuf, yang menurutnya tidak bisa dipisahkan dari keseluruhan agama Islam. Ringkasnya, ia menyatakan :

Babkean jike tasawn itu adalah disiplin yang lebih berurusan dengan masalah-masalah inti (batin), maka ia juga berarti merupakan inti keagamaan (religiusitas) yang bersifat esoteris. Dari sudut ini maka "ilmu" tasawuf tidak lain adalah penjabaran secara nalar (nazar, teori ilmiah) tentang apa sebenarnya taqwa itu.

\section{Kontroversi dalam Tasawuf.}

Sekalipun tasawuf mendasarkan ajaran-ajarannya pada al-Qur'an dan Sunnah, khususnya dalam soal-soal doktrin, namun tidak dapat dipungkiri bahwa dalam perkembangannya, esoterisme Islam ini menerima, atau barangkali lebih tepat memasukkan, unsur-unsur asing dari luar, hingga dapat menimbulkan ekses-ekses negatif. Dalam hal ini, sikap Nurcholish Madjid memang sangat hati-hati, menurutnya ekses-ekses yang timbul baik karena pengaruh langsung maupun tidak langsung, seluruhnya tidak dapat dicegah. Lebih jelas Nurcholish Madjid mengatakan :

Sebetulnya ekses-ekses tersebut ada dalam rangkaian suatu susunan ajaran dan paham yang sangat komplek dan sulit dipahami. Agaknya tekanan yang berlebihan

\footnotetext{
${ }^{18}$ Lihat, Nurcholish Majid, "Tasawnf sebagai Inti...", hal. 4-5

${ }^{19}$ Nurcholish Madjid, Islam Dontrin dan ...", hal. 260.

${ }^{20}$ Ibid., hal. 261-262.
} 
pada kemampuan intuisi pribadi dalam mengenali Tuban telah memberi peluang bagi tumbubnya dorongan-dorongan subyektif untuk menemukan dan mengemukakan cara-caranya sendiri dalam menjalankan amalan rubani. ${ }^{21}$

Nampaknya Nurcholish Madjid, dengan pendapatnya di atas, ia dapat memaklumi terjadinya ekses-ekses demikian, karena itulah tentang terjadinya pandangan kontroversi dan penghakiman terhadap beberapa tokoh tasawuf, misalnya tuduhan sesat kepada paham wahdat al-wujud di mata abl al-dhawabir, menurut Nurcholish Madjid hal itu akan memiliki implikasi yang serius, karena menyangkut masalah sampai dimana seseorang bisa dan berhak menilai pengalaman keruhanian seseorang yang bersifat pribadi (individuation). ${ }^{22}$ Diakuinya, oleh karena pengalaman mistik hampir mustahil dikomunikasikan kepada orang lain, dan lebih merupakan milik pribadi, maka sering terjadi adanya tingkah laku eksentrik dan "di luar garis". Apa yang diungkapkan para sufi tentang suatu "hakikat", dan itu adalah suatu rasa yang bersifat intuitif, maka tidak jarang munculnya "keliaran" menjadi tinggi sekali.

Selain itu, kesulitan lainnya adalah dalam memahami literatur tasawuf, yang menurut Nurcholish Madjid, bahwa pengungkapan ide dan ajaran di dalamnya sering menggunakan kata kiasan (matsal) dan perlambang (rams). Karena itu ungkapanungkapan yang ada harus dipahami dalam kerangka interpretasi metaforis atau tafsir batini (ta'wil). Dan adalah ta'wil itu, lanjutnya, yang memang yang menjadi metode pokok mereka dalam memahami teks-teks suci, baik kitab suci maupun hadits Nabi. Maka meskipun mereka menggunakan ta'wil, Nurcholish Madjid kemudian meyakinkan, bahwa mereka sebenarnya tetap berpegang kepada sumber-sumber suci itu. Hanya saja, sejalan dengan metode itu, mereka kata Nurcholish Madjid lagi, tidak memahami sumber-sumber itu menurut bunyi lahiriah tekstualnya. Inilah pangkal kontroversi mereka dengan kaum Syari'ah. ${ }^{23}$ Karena itu dalam menyikapi sikap-sikap kontroversial para sufi itu, Nurcholish Madjid nampaknya masih menyimpan sikap apresiasi yang tinggi pada pengalamam mistik kaum sufi dengan menyatakan :

...dalam semangat empatik, mungkin justru pengalaman mistis kaum sufi harus dipandang sebagai bentuk pengalaman keagamaan yang sejati. Sepertipengalaman Nabi dalam Mi'raj yang tak terlukiskan, sehingga karenanya juga tak terkomunikasikan, pengalaman mistis kaum sufipun sesunggubnya berada di luar kemampuan rasio untuk. menggambarkannya. Kaum suf gemar mengatakan babwa untuk. bisa mengetahui apa bakikat pengalaman itu, seseorang hanya harus mengalami sendiri...tidak mungkinlah menjelaskan rasa manisnya madu jika orang tidak pernab mencicipinya sendiri. ${ }^{24}$

\footnotetext{
${ }^{21}$ Nurcholish Madjid, Bilik-Bilik Pesantren..., hal. 50.

${ }^{22}$ Menurut Cak Nur dengan adanya proses individuation dalam agama, maka sebetulnya kita tidak bisa mempersepsi dengan pengalaman orang lain, karena sifatnya unik. "Individution" adalah keunikan dari macam-macam pribadi dengan pengalaman-pengalaman keagamaannya sendiri, berbeda dengan "individualization", jargon yang ada di Barat, yang mengandung pernyataan bahwa agama adalah urusan pribadi. Lihat, Nurchlish Madjid, "Tbn 'Arabi dan Tasawnf" dalam Sukardi (Ed.), Kuliah-Kuliah Tasawnf, (Bandung : Pustaka Hidayah, 2000), hal. 126.

${ }^{23}$ Nurcholish Madjid, Islam Doktrin dan ..., hal. 264.

${ }^{24}$ Ibid., hal. 265.
} 


\section{Neo-sufisme.}

Walaupun Nurcholish Madjid menyimpan sikap apresiatif yang tinggi pada inti ajaran tasawuf, dengan tetap melihat adanya segi-segi yang otentik dalam tasawuf dan diperlakukannya begitu rupa, sehingga tampak sebagai kelanjutan wajar dari semangat ajaran Islam. Namun sebagai seorang reformis, beliau masih tetap mengingatkan bahwa kecenderungan kepada aspek esoterisme itu, karena tekanan yang berlebihan, dapat menghasilkan kepincangan yang menyalahi prinsip ekuilibrium dalam Islam, dan menyalahi ajaran Islam seperti zuhud atau asketisme yang pasif, isolatif dan "anti dunia”, serta ekses-ekses negatif dari pemujaan kepada wali, kultus individu terhadap guru dan sebagainya yang menjurus kepada hilangnya sifat kritis dan kreatif.

Dalam hal ini, ajaran tasawuf perlu dipagari begitu rupa hingga tak menimbulkan ekses-ekses negatif tersebut dan menimbulkan kemunduran dan kepasifan akibat salah dalam bertasawuf. Itulah tasawuf yang sehat yang dikehendakinya. Nurcholish Madjid mengatakan :

Menurut hemat saya, sufisme yang sehat akan berfungsi dengan sehat pula manakala tingkat intelektualitas dari para penganut sufi telah cukup tinggi. Adalah sebuah sikap yang benar jika para ulama melarang umat Islam memasuki dunia sufi sebelum berbenah diri dengan syari'at (fiqih). ${ }^{25}$

Apa yang dimaksud Nurcholish Madjid sebagai tasawuf yang sehat itulah nampaknya yang dimaksudkannya sebagai "Neo-sufisme", yaitu suatu jenis tasawuf yang mempunyai ciri utama berupa tekanan kepada motif moral dan mengharuskan praktek dan pengamalannya tetap dalam kontrol dan lingkungan ajaran al-Qur'an dan Sunnah. Nurcholish Madjid sendiri menggambarkan "Neo-sufisme" itu sebagai :

Sebuah esoterisme atau penghayatan keagamaan batini yang menghendaki bidup aktif dan terlibat dalam masalah-masalah kemasyarakatan. Sesekali menyingkirkan diri ("uzlah) mungkin ada baiknya, tapi jika hal itu dilakukan untuk menyegarkan kembali wawasan dan meluruskan pandangan, yang kemudian dijadikan titik tolak. untuk pelibatan diri dan aktifitas segar lebih lanjut. ${ }^{26}$

Dari kutipan di atas, nampak jelas penekanan Nurcholish Madjid bahwa jalan tasawuf itu perlu pelibatan diri dalam masyarakat secara lebih kuat, sufisme diinginkannya semacam sebuah spiritualisme sosial. Lalu bagaimana dalam prakteknya ? Untuk itu ia mencontohkan seperti apa yang dikemukakan dalam sebuah risalah kecil yang berjudul al-Ruhaniyat al-Ijtima'iyah karya Dr. Sa'id Ramadhan, pemimpin Islamic Centre, Jenewa, Swiss, yang disebutnya sebagai zuhud atau asketisme "modern". Ringkasnya adalah : (1) Membaca dan merenungkan makna kitab suci al-Qur'an; (2) Membaca dan mempelajari makna kehadiran Nabi SAW. melalui Sunnah dan Sirah (biografi) beliau; (3) Memelihara hubungan dengan orang-orang saleh seperti para "ulama" dan tokoh Islam yang zuhud; (4) Menjaga diri dari sikap dan tingkah laku tercela; (5) mempelajari hal-hal tentang ruh dan metafisika dalam al-Qur'an dan alSunnah, dengan sikap penuh percaya; (6) Melakukan ibadat-ibadat wajib dan sunnah, seperti sembahyang lim awaktu dan tahajjud. ${ }^{27}$

\footnotetext{
${ }^{25}$ Nurcholish Madjid, "Tasawnf sebagai Inti...", hal. 6.

${ }^{26}$ Nurcholish Madjid, Islam Agama Peradaban ... hal. 103.

${ }^{27}$ Ibid., hal. 94-95.
} 
Kemudian bagaimana dengan pengalaman mistik para sufi ? Neo-sufisme itu tidak mempersoalkan dan masih mengakui sampai pada batas-batas tertentu, kebenaran klaim tasawuf intelektual, seperti adanya kasyf (pengalaman penyingkapan kebenaran) kaum sufi atau ilham intuitif. Pengalaman metafisis pribadi seperti kasyf itu, kata Nurcholish Madjid adalah absah, namun bersifat pribadi dan tidak berlaku untuk orang lain. Juga tidak boleh diklaim sebagai mesti benar, sebab kebenaran suatu pengalaman kasyfadalah sebanding dengan kebersihan hati yang bersangkutan. Pengalaman kasyf merupakan sumber kebahagiaan pribadi yang tiada taranya, namun hal itu tidak dapat disertai orang lain, atau orang lain tidak dapat disertakan di dalamnya. ${ }^{28}$

Setiap ajaran esoterik tentu memiliki segi-segi eksklusif, yang menyangkut hal-hal yang "rahasia". Jadi tidak dapat dibuat untuk umum, karena bobot keruhaniannya yang berat membuatnya sukar dimengerti oleh kaum awam, atau mudah menimbulkan salah paham pada mereka. Karena itu segi-segi eksklusif tersebut seyogyanya tidak dipahami seseorang melalui kegiatan pribadinya semata, melainkan dipahami dari seseorang guru pembimbing (mursyid) yang sudah diakui kewenangannya. Disinilah nampaknya Nurcholish Madjid melihat absahnya keberadaan tarekat-tarekat yang muncul dalam sejarah tasawuf.

Lebih lanjut ia menyatakan:

...kehidupan sufistik memang untuk maqam tertentu. Akan tetapi dibenarkan juga adanya bentuk sufisme populis, yang diperuntukekan bagi orang awam. Ajaran sufi untuk orang awam ini biasanya melabirkan diri dalam bentuk batasan-batasan akblak.

Oleh karena itu, dalam bukum Islam, akblak sebagai etik, tidak berkembang secara terpisah, melainkan menjadi bagian dari tasawnf. ${ }^{29}$

Tasawuf dalam batasan-batasan akhlak yang diperuntukkan bagi orang awam itulah, yang dalam istilah populer di kalangan Nahdhatul 'Ulama sebagai "thariqah mu'tabarah", dimaksudkan Nurcholish Madjid dengan sebuah tarekat yang dapat diterima keberadaannya. Bagi Nurcholish Madjid gerakn-gerakan tarekat dalam tasawuf, pada prinsipnya adalah hasil ijtihad dalam usaha mendekatkan diri kepada Allah SW'T., maka dalam menilainya, tidak dibenarkan sikap pro-kontra yang bernada kemutlak-mutlakan. ${ }^{30}$ Bahkan lebih dari itu Nurcholish Madjid melihat, dengan keberadaan organisasi tarekat dan para pembimbingnya itu, tasawuf dapat tercegah dari kemungkinan mengalami gerak sentripetal sehingga menimbulkan kesesatan yang tidak dikehendaki, karena adanya pembimbingan itu. ${ }^{31}$

Dapatkah diperkirakan masa depan tarekat di tengah-tengah masyarakat masa kini ? Menurut Nurcholish Madjid, karena kebutuhan keruhanian merupakan kenyataan esensial tentang kemanusiaan, yang menurut al-Qur'an merupakan kelanjutan perjanjian primordial manusia dengan Tuhan, maka masa depan tarekat, atau lebih umum lagi tasawuf itu, akan dengan sendirinya sangat tergantung kepada "seberapa jauh ia mampu menyediakan jawaban-jawaban spiritual bagi kebutuhan manusia

\footnotetext{
${ }^{28}$ Ibid., hal. 103..

${ }^{29}$ Nurcholish Madjid, , Tasawnf sebagai Inti... hal. 9

${ }^{30}$ Lihat, Nurcholish Majid, Islam Agama Peradaban ..., hal. 115.

${ }^{31}$ Lihat, Ibid., hal. 113.
} 
modern". Lebih-lebih lagi tambahnya, manusia modern sekarang adalah manusia yang kritis, serba rasional dan bergandengan dengan itu, cenderung lebih berpikir menurut kerangka pandangan yang lebih menekankan masalah fungsional dan substansial. Karena itu tarekat sebagai suatu bentuk mata air keruhanian, mungkin akan mengalami "perubahan" segi-segi lahiriahnya, misalnya masalah pengorganisasian dan struktur hubungan fungsional antara mursyid dan murid. Namun, kata Nurcholish Madjid, hampir dapat dipastikan bahwa inti ajaran keruhaniannya akan tetap bertahan, dalam satu dan lain bentuk. ${ }^{32}$

\section{Pendidikan Tasawuf bagi generasi muda}

Karena bidang garapan tasawuf itu berada dalam inti keagamaan yaitu kesadaran keagamaan (religiusitas) yang melahirkan masyarakat etis atau akhlaqi, maka pengembangannya, khususnya bagi generasi muda, terkait dengan problem metodikdidaktik. Nurcholish Madjid melontarkan kritik terhadap metodik-didaktik yang ada selama ini. Adalah kenyataan, katanya, bahwa pengajaran agama di lembaga-lembaga pendidikan kita umumnya didominasi oleh orientasi lahiriah Fiqh dan Kalam, yakni segi-segi eksoteris. Karena dominasi fiqh, itu anak didik lebih paham misalnya, syarat dan rukun bagi sah-tidaknya shalat, tanpa dengan mantap mengetahui apa sesungguhya makna shalat itu bagi pembentukan diri pribadinya, lahir dan batin. Dan karena dominasi Kalam, ia lebih mampu bagaimana membuktikan bahwa Tuhan ada, tanpa memiliki keinsyafan yang cukup mendalam tentang apa makna kehadiran (rasa ketuhanan dalam kalbu) itu dalam hidup ini. ${ }^{33}$

Maka dalam masalah metodik-didaktik ini, harus ditemukan kata Nurcholish Madjid, cara bagaimana untuk menyadarkan anak didik akan makna ibadat-ibadat lahiriah, dan apa yang sebenarnya diharapkan dari ibadat-ibadat itu bagi pembentukan diri pribadinya, yakni akhlaqnya. Disini tentu, katanya lagi, mutu dan kemampuan tenaga pengajar itu sendiri menjadi sangat menentukan.

Karena itu Nurcholish Madjid mengusulkan adanya kemungkinan penjenjangan pendidikan atau pengajaran tasawuf di sekolah-sekolah atau madrasah-madrasah. Sesuai dengan perkembangannya, untuk anak didik tingkat Ibtidaiyah atau Sekolah Dasar, yang jelas diperlukan ialah pengetahuan tentang pokok-pokok agama seperti Rukun Islam dan Rukun Iman, serta kemampuan untuk melaksanakan secara benar ibadat sehari-hari. Namun janganlah dibiarkan tumbuh dengan orientasi lahiriah semata. Maka penting sekali ditanamkan rasa keikhlasan dalam ibadat dan dalam perbuatan yang lain. Ditanamkan sedini mungkin penghayatan akan arti dan makna bacaan-bacaan dalam shalat. Juga harus disadarkan bahwa shalat adalah peristiwa yang amat penting bagi dirinya, karena merupakan kesempatan ber-tawajuh dengan Tuhan. Inilah bibit keikhlasan, dan pangkal tolak akhlaq yang mulia, karena hal itu akan menumbuhkan sikap hidup yang diliputi oleh semangat kehadiran dan pengawasan Tuhan dalam hidup ini. ${ }^{34}$

Pada jenjang tingkat Tsanawiyah tidak jauh berbeda dengan perkembangan tingkat Ibtidaiyah, tapi mungkin pendidikan tasawuf dan akhlaq ini sudah harus mulai

\footnotetext{
${ }^{32}$ Lihat, Ibid., hal. 117-118.

${ }^{33}$ Nurcholish Madjid, Masyarakat Religius, (Jakarta : Paramadina, 1997), hal. 141.

${ }^{34}$ Ibid., hal. 143.
} 
dikembangkan dengan memperkenalkan konsep-konsep keagamaan atau tasawuf yang mengarah kepada pembentukan pribadi yang kuat seperti, selain ikhlas, adalah sabar, tawakkal, inabah. khauf dan raja', taubat, taqarrub, pemaaf, toleran, ramah dan seterusnya, dengan kutipan-kutipan ayat-ayat dari al-Qur'an yang menerangkan tentang kualitas orang-orang yang beriman tersebut. ${ }^{35}$

Karena sistem pendidikan selalu berada dalam suatu kontinuitas yang tak terputus-putus, maka pada jenjang 'Aliyah pun pendidikan tasawuf atau akhlaq harus merupakan kelanjutan wajar dari yang ada sebelumnya. Pengembangan lebih lanjutnya adalah dengan bertitik-tolak dari penanaman akan pemahaman tentang makna "namanama indah" (al-asma' al-busna) dari Tuhan dengan tujuan memberikan penyadaran dan petunjuk bagaimana mempersepsi Tuhan secara benar, karena persepsi manusia terhadap-Nya bisa tidak seimbang (tidak utuh), yang biasanya amat terpengaruh oleh pengalaman hidup manusia itu sendiri. Karena itu para sufi sering mengemukakan perlunya meniru kualitas Tuhan atau meniru akhlak Tuhan (takhallaqu bi akhlaq-I'l-Lah). Juga, sesuai dengan kemampuan kognitifnya, dapat mulai diperkenalkan kepada para murid secara garis besar sejarah tumbuhnya tasawuf, dengan para tokoh-tokohnya dan berbagai aliran tarekat-nya.

Jadi jelas dalam pandangan Nurcholish Madjid bahwa tasawuf atau akhlaq itu harus diajarkan kepada anak didik Muslim sebagai dimensi kedalaman keagamaan yang dapat saja terancam hilang karena dominasi segi-segi lahiriah dalam beragama.

\section{Simpulan}

Walaupun masalah tasawuf bukan merupakan tema-tema sentral karya-karya Nurcholish Madjid, namun di dalam gagasan-gagasan pembaharuannya yang sarat dengan wawasan keilmuan, kemodernan dan kemanusiaan, dapat ditemukan pandangan-pandangannya yang menyimpan sikap yang apresiatif dan rasa kepeduliannya terhadap tasawuf yang diakuinya sebagai salah satu cabang keilmuan tradisional klasik.

Sebagaimana telah dijelaskan bahwa Nurcholish Madjid melihat bahwa inti keberagamaan itu justru terletak dalam tasawuf, sebagai kelanjutan wajar dari semangat ajaran Islam, dan mempunyai akar yang kuat (built-in) dalam al-Qur'an. Inti pandangannya tentang tasawuf ialah sufisme yang sehat (Neo-sufisme), yang menekankan motif moral dan praktek yang tetap dalam kontrol al-Qur'an dan Sunnah, yang mengandung unsur ketauhidan dengan tidak mengizinkan adanya paham kultus, menekankan taqarrub dengan menghayati sebaik-baiknya makna ibadat dan melalui ibadat itu mendekatkan diri kepada Allah. Kemudian ditanamkan akhlak al-karimah, di mana makna ekspresi lahiriah keagamaan adalah pendidikan moralitas, etika dan akhlak mulia, dan sebagai kelanjutannya harus aktif terlibat dalam hidup sosial. Butir-butir dari paham Nurcholish Madjid ini, sangat relevan dengan kehidupan keagamaan di negeri kita kini dan di masa mendatang, yang haus akan dimensi keruhanian (spiritual), yang sejauh tasawuf mampu menyediakan jawaban-jawaban bagi kebutuhan manusia modern.

\footnotetext{
${ }^{35}$ Ibid., hal. 144.
} 
Sambil mengutip pendapat H.A.R. Gibb bahwa ada dua golongan yang menolak tasawuf dengan titik-tolak yang berbeda yaitu, kaum modernis-sekularis Kemalis di Turki dan kaum puritanisme-ortodoks Wahabi di Saudi Arabia, Nurcholish Madjid mengatakan bahwa barangkali memang benar tuduhan bahwa tasawuf pernah menyebabkan kaum Muslim mundur, tetapi barangkali patut diperhatikan seruan H.A.R. Gibb untuk menelaah kembali kemungkinan keringnya rasa keagamaan yang mendalam, yang bakal diderita kaum Muslim sendiri khususnya, dan umat manusia pada umumnya karena kekakuan puritanisme kaum reformis dan kesemberonoan modernis kaum sekularis. Karena itu menurut Nurcholish Madjid hal strategis yang dapat dilakukan pada saat ini adalah meninjau kembali segi-segi kebaikan dan kekuatan tasawuf itu sendiri serta menelitik segi-segi kelemahannya, ditambah lagi yang sangat diperlukan, yaitu peningkatan taraf kecerdasan umat Islam pada umumnya ${ }^{36}$

\section{Daftar Pustaka}

Djohan Effendi, Sufisme Dan Masa Depan Agama, (Jakarta : Pustaka Firdaus, 1993).

Greg Barton, Gagasan Islam Liberal di Indonesia, (Terj. Nanang Tahqiq), Jakarta :

Paramadina, 1999.

Nurcholish Madjid, Bilik-Bilik Pesantren : Sebuab Potret Perjalanan, (Jakarta : Paramadina, 1997).

Nurcholish Madjid, Dialog Keterbukaan : Artikulasi Nilai Islam dalam Wacana Sosial Politik Kontemporer, Jakarta : Paramadina, 1998.

Nurcholish Madjid, "Tbn 'Arabi dan Tasawuf” dalam Sukardi (Ed.), Kuliah-Kuliah Tasawuf, (Bandung : Pustaka Hidayah, 2000).

Nurcholish Madjid, Islam Agama Peradaban : Membangun Makna dan Relevansi Doktrin Islam dalam Sejarah, Jakarta : Paramadina, 1995.

Nurcholish Madjid, Islam Doktrin dan Peradaban : Sebuab Telaah Kritis tentang Masalah Keimanan, Kemanusiaan dan Kemodernan, (Jakarta : Paramadina, 1992).

Nurcholish Madjid, Masyarakat Religius, (Jakarta : Paramadina, 1997).

Nurcholish Madjid, "Tasawuf Sebagai Inti Keberagamaan” dalam Majalah Pesantren, No.3/Vol. II/1985.

${ }^{36}$ Ibid., hal. 145. 